\title{
Parent selection for cocoa resistance to witches'-broom
}

\author{
Stela Dalva Vieira Midlej Silva(1), Edna Dora Martins Newman Luz ${ }^{(1)}$, José Luis Pires ${ }^{(1)}$, Milton Macoto Yamada(1) \\ e Lindolfo Pereira dos Santos Filho(1)
}

(1)Comissão Executiva do Plano da Lavoura Cacaueira, Centro de Pesquisas do Cacau, Caixa Postal 07, CEP $45600-970$ Itabuna, BA.
E-mail: stela@ceplac.gov.br, ednadora@cepec.gov.br, joseluis@cepec.gov.br, macoto@cepec.gov.br, lindolfo@cepec.gov.br

\begin{abstract}
The objective of this work was to identify genotypes with high general combining ability for resistance to witches'-broom (Moniliophthora perniciosa) in populations formed from a first cycle of recurrent selection. Highly productive and resistant clones from different origins were interbred using the North Carolina II design. The clones SCA 6, CSUL 7, RB 39, CEPEC 89, OC 67, BE 4, EEG 29 and ICS 98 were used as paternal parents, while the maternal ones were NA 33, CCN 10, IMC 67, P 4B, CCN 51, CEPEC 86, SGU 54 and ICS 9. Twenty days after germination, 56 seedlings of each cross (four replicates of 14 seedlings) received the inoculation of a $1-\mathrm{mL}$ suspension with $7.5 \times 10^{4}$ basidiospores $\mathrm{mL}^{-1}$. Symptoms were evaluated 60 days after inoculation. Significant differences were observed among paternal and among maternal parents, for resistance to witches'-broom assessed according to the proportion of progeny seedlings with the disease symptoms. Differences were also observed between groups of mothers or fathers previously defined as resistant, and groups previously defined as susceptible. It is possible to obtain a combination of genes that can increase the level of resistance to witches'-broom directly from the first cycle of recurrent selection.
\end{abstract}

Index terms: Moniliophthora perniciosa, Theobroma cacao, disease integrate management, early selection, genetic resistance.

\section{Seleção de progenitores de cacaueiro quanto à resistência à vassoura-de-bruxa}

Resumo - O objetivo deste trabalho foi identificar genótipos com alta capacidade geral de combinação quanto à resistência à vassoura-de-bruxa (Moniliophthora perniciosa), em populações formadas a partir do primeiro ciclo de seleção recorrente. Clones altamente produtivos e resistentes à vassoura-de-bruxa, de diferentes procedências, foram intercruzados com uso do delineamento Carolina do Norte II. Como progenitores paternos, foram utilizados os clones SCA 6, CSUL 7, RB 39, CEPEC 89, OC 67, BE 4, EEG 29 e ICS 98 e, como maternos, NA 33, CCN 10, IMC 67, P 4B, CCN 51, CEPEC 86, SGU 54 e ICS 9. Vinte dias após a germinação, 56 plântulas de cada cruzamento (quatro repetições de 14 plântulas) receberam inoculação de $1 \mathrm{~mL}$ de suspensão com $7,5 \times 10^{4}$ basidiósporos $\mathrm{mL}^{-1}$. Os sintomas foram avaliados 60 dias após a inoculação. Foram observadas diferenças significativas, entre os progenitores paternais e entre os progenitores maternais, quanto à resistência à vassoura-de-bruxa avaliada pela proporção de plântulas das progênies com sintomas da doença. Diferenças também foram observadas entre grupos de progenitores paternais ou maternais previamente definidos como resistentes, e grupos previamente definidos como suscetíveis. É possível obter, diretamente de primeiros ciclos de seleção recorrente, uma combinação de genes que possa aumentar a resistência à vassoura-de-bruxa.

Termos para indexação: Moniliophthora perniciosa, Theobroma cacao, manejo integrado da doença, seleção precoce, resistência genética.

\section{Introduction}

The introduction of witches'-broom disease (Moniliophthora perniciosa) to cocoa plantations of Bahia state (Pereira et al., 1989) was responsible for the decline in productivity that caused Brazil to fall from second to fifth world largest cocoa producer. This disease is being considered as the most significant one in the cocoa-growing region of southern Bahia, and stands out as a factor of economic and social disturbance, having triggered a widespread rural exodus and the abandonment of countless farms (Luz et al., 1997; Trevisan, 1999).

To cope with this problem, the Centro de Pesquisas com Cacau (Cepec) has developed numerous programs focused on the integrated management of the disease, which include enhancing the resistance level and durability of new commercial varieties. So far,

Pesq. agropec. bras., Brasília, v.45, n.7, p.680-685, jul. 2010 
processes of recurrent selection have been performed using populations produced by crossings in a North Carolina II design (Comstock \& Robinson, 1952), with three basic types: population A, from crossings among Upper Amazonian materials (Cheesman, 1944) and designed mainly for the next generation of parent selection, focused on resistance to witches'-broom and black pod diseases, fat content, and combining ability with the progenitors of the population B; population B, composed of crossings among Lower Amazonian and Trinitarian materials (Cheesman, 1944), also designed for progenitor selection based mainly on fruit and seed characteristics, production, and combining ability with the progenitors of population $\mathrm{A}$; and population $\mathrm{AB}$, which comprises crossings between Upper Amazonian and Lower Amazonian/Trinitarian plants, for heterosis exploration, obtained by the combination of materials with wide genetic distinction, and the addition of interesting characteristics, aimed at selecting clones and progenies for commercial planting (Pires et al., 1999). The clones of each population were selected in the Cepec's germplasm collection based on their "per se" performance as for the important agronomic traits already mentioned, and taken also into account the genetic diversity of parents and the possibility of associating resistance genes from different sources (Pires, 2003).

Recurrent selection in perennial crops is becoming a commonly used technique among breeders (Cochard et al., 1993; Baudouin et al., 1997; Leroy et al., 1997). Cacao breeding programs using this strategy have been initiated in the Ivory Cost (Paulin, 1995; Pokou et al., 2009), Malaysia (Lockwood \& Pang, 1993) and Brazil (Pires, 2003; Monteiro et al., 2006). Promising results in the accumulation of genes for resistance to black pod disease (Adu-Ampomah et al., 2006; N'Goran et al., 2006; Pokou et al., 2009) are already being obtained.

The objective of this work was to identify genotypes with high general combined ability for resistance to witches'-broom (Moniliophthora perniciosa) in populations formed from a first cycle of recurrent selection.

\section{Materials and Methods}

Crosses of two genotype groups were carried out according to the North Carolina II design (Comstock \& Robinson, 1952), and the progenies were evaluated for resistance to witches'-broom disease (Table 1). Two genotypes among the maternal (ICS 9 and SGU 54) and paternal (ICS 98 and EEG 29) groups showed higher susceptibility to witches'-broom in a "per se" field evaluation, while the others showed some degree of resistance in the germplasm evaluation (Pires, 2003).

A completely randomized design was used, with four replicates of at least 14 plants each, according to the availability of seeds. Sixteen trials were done using 49 of the 64 expected progenies. Since it was not possible to evaluate all the combinations at the same time, emphasis was given to comparing progenitors and progenies with both parents previously identified as resistant, and progenies with only one - or not even one - resistant progenitor.

The inoculum was obtained from vegetative brooms and infected pods under a shed covered by screen tissue of $50 \%$ shade and from vegetative brooms hung in horizontally stretched wires under open sky. Infected cacao pods were placed on a table with wire screen surface for the production of spores, following the methodology described by Suarez-Capello (1977) and Rocha \& Wheeler (1985), except during the rainy days.

Ripe basidiomata were collected and disinfected in $1 \%$ chloramphenicol solution, dried on sterilised filter paper, and fastened wiht vaseline (Silinol SG) in glass covers, with the hymenium positioned upside-down

Table 1. Mother and father progenitors crossed to obtain the studied progenies.

\begin{tabular}{lc}
\hline Clone & Progenitor type and origin ${ }^{(1)}$ \\
\hline CCN 10 & Mother \\
CCN 51 & Hybrid, Ecuador (B) $)^{(2)}$ \\
CEPEC 86 & Hybrid, Ecuador (B) \\
ICS 9 & Domesticated, Bahia, Brazil (B) \\
IMC 76 & Domesticated, Trinidad (B) \\
NA 33 & Wild, Iquitos, Peru (A) \\
P 4B & Wild, Nanay River, Peru (A) \\
SGU 54 & Wild, Iquitos, Peru (A) \\
& Domesticated, Guatemala (B) \\
BE 4 & Father \\
CSUL 7 & Wild, Pará, Brazil (B) \\
CEPEC 89 & Wild, Acre, Brazil (A) \\
EEG 29 & Unknown (A) \\
ICS 98 & Domesticated, Bahia, Brazil (B) \\
OC 67 & Domesticated, Trinidad (B) \\
RB 39 & Domesticated, Ocumare, Venezuela (B) \\
SCA 6 & Wild, Acre, Brazil (A) \\
\hline
\end{tabular}

${ }^{(1)}$ According to Wadsworth et al. (1997). ${ }^{(2)}$ The letters inside the parenthesis refers to the populations A or B used in this study. 
in a beaker containing $16 \%$ glycerin solution, so that the basidiospores were liberated into this solution. The basidiospore suspension, obtained after calculation of spore concentrations, was used fresh or kept in 2.5-mL flasks stored in liquid nitrogen until use. Before stockpiling, germination tests were performed to determine the viability of the basidiospores, after reducing the glycerin concentration to $3 \%$ (Frias et al., 1995). Only suspensions that had more than $80 \%$ germination were used as inocula. Immediately before inoculation, the concentration of the suspensions was adjusted to $7.5 \times 10^{4}$ basidiospores $\mathrm{mL}^{-1}$.

One day before the inoculation in progeny seedlings, leaf size was reduced to $1 / 3$, in order to accelerate the apical growth by exposing the apical bud to infection. Inoculations were carried out using the semi-automated system of inoculation and incubation described by Frias (1987) and optimized by Silva et al. (2000). Seedlings were kept in an acclimatized chamber, for 24 hours, at $25^{\circ} \mathrm{C}$ and relative humidity of $100 \%$, and then they were transferred to a greenhouse under normal environmental conditions and irrigation, up to the evaluation date.

Sixty days after inoculation, seedlings were individually evaluated for the presence of the following symptoms: terminal broom (TB), axillary broom (AB) and cotyledonary broom (CB). The data were taken as presence (score 1) or absence (score 0) of each symptom type.

The analyses considered the proportion of seedlings with at least one of the described symptoms and a model with the following sources of variation was built: father, mother, and father $\mathrm{x}$ mother interaction. The seedlings variable proportions of disease symptoms were transformed $\left[\operatorname{arc} \sin (\mathrm{x})^{0.5}\right.$ ] for standardization of the distribution and homogenization of variances.

For the analysis of the general combining ability differences, the parental corrected means were estimated through the reduction of the model by the exclusion of the interaction - which was necessary because of the unbalanced data -, using LSmeans SAS (SAS Institute, 1988). The differences were interpreted using the $\mathrm{F}$ test. The comparisons of progeny means were made considering Tukey's test at $5 \%$ of probability, by using the harmonic mean of replicates (Means) according to SAS (SAS Institute, 1988). The consistency of the evaluation method and how it reflected the field behavior were analyzed through contrasts among the means of the progenies of clones previously (Pires, 2003) considered as resistant, and among the means of progenies of the clones previously considered as susceptible. As maternal genitors, NA 33, CCN 10, IMC 67, P 4B, CCN 51 e CEPEC 86 (resistants) x SGU 54 e ICS 9 (susceptibles) were evaluated. Evaluations were done for clones as paternal genitors, with SCA 6, CSUL 7, RB 39, CEPEC 89, OC 67, BE 4 (resistant group) versus EEG 29 e ICS 98 (susceptible group). The $\mathrm{F}$ test and the corrected means of the reduced model previously described were used to interpret the differences. With an identical purpose, the correlation between the field data of each parental clone "per se" evaluation (Pires, 2003) and the means of their progenies were also analyzed.

In order to evaluate the effect of the combination of resistance genes, contrasts were done among the means of progenies that resulted from crosses between two resistant parents and those in which only one of the parents was considered resistant, based on the previous "per se" field evaluation (F test of the complete model).

\section{Results and Discussion}

Parental and maternal progenies showed significant differences in the disease proportions of the seedlings, which showed the existence of addictive effects for resistance to witches'-broom(Table2). The fatherx mother interaction effect was also significant. This interaction represents the occurrence of different patterns of specific combining abilities, but it should be emphasised that such interactions are inflated by the effect of different trials - different progenies evaluated in different periods: 16 trials in total, since it was not possible to evaluate all the combinations at the same time.

Significant differences were observed for the contrast between the means of the progenies of the mothers'

Table 2. Analysis of variance for the proportions ${ }^{(1)}$ of seedlings with disease symptoms, of the progenies from the paternal clones SCA 6, CSUL 7, RB 39, CEPEC 89, OC 67, BE 4, EEG 29 and ICS 98, and maternal clones NA 33, CCN 10, IMC 67, P 4B, CCN 51, CEPEC 86, SGU 54 and ICS 9.

\begin{tabular}{lcccc}
\hline Source of variation & DF & Mean square & F value & P \\
\hline Mother & 7 & 0.56701760 & 16.55 & $<0.0001$ \\
Father & 7 & 0.18984126 & 5.54 & $<0.0001$ \\
Mother x father & 34 & 0.13114849 & 3.83 & $<0.0001$ \\
Error & 143 & 0.03426844 & - & - \\
\hline
\end{tabular}

${ }^{(1)} \operatorname{Arc} \sin (\mathrm{x})^{0.5}$. 
group previously identified as resistant, according to germplasm evaluation (NA 33, CCN 10, IMC 67, P 4B, CCN 51 and CEPEC 86), and the means of the group previously identified as susceptible (SGU 54 and ICS 9) $(\mathrm{p}<0.01)$. In addition, differences in the proportions of seedlings with disease symptoms were observed for the contrast between the means of resistant fathers, grouped according the "per se" evaluation (SCA 6, CSUL 7, RB 39, CEPEC 89, OC 67, BE 4), and the means of the susceptible group (EEG 29 and ICS 98) $(\mathrm{p}<0.01)$. Significant Pearson's correlation $(\mathrm{p}<0.05)$ for fathers $(0.73)$ and for mothers $(0.84)$ were observed between the number of witches'-broom per plant per year values, according to Pires (2003), and the corrected means of the proportions of progeny seedlings with disease symptoms. This confirmed the efficiency of the "per se" evaluation in selecting genotypes with potential for high general combining ability and of the evaluation methodology used (inoculation through semi-automatic system) as an indicator of the field behaviour for witches'-broom resistance, for early selection.

Surujdeo-Maharaj et al. (2004) evaluated the witches'-broom resistance of 14 genotypes and their offspring and also found high correlations among results of artificial inoculation $(30-\mu \mathrm{L}$ agar drops, containing $35 \times 10^{4}$ basidiospores $\mathrm{mL}^{-1}$ ), in nursery and natural infection in the field.

In the fathers group, the progenies of the clone ICS 98 had the highest mean, differing from all the progenies, except for the clone EEG 29 (Table 3). ICS 98 and EEG 29 were both previously recognized as the two most susceptible clones in the fathers group "per se" evaluation (Pires, 2003). The progenies of Scavina 6 generated the smallest mean, but not significantly different from CEPEC 89 and CSUL 7.

Among the mothers, P 4B had the lowest mean, which did not differ from CCN 10, NA 33 and CEPEC 86 (Table 4). The means of these four families were different from those of genotypes previously identified as susceptible: SGU 54 and ICS 9. The clone SGU 54 had the highest mean, but did not differ from that of ICS 9 or CCN 51. The later clone is considered to be resistant (Pires, 2003; Bastos \& Albuquerque, 2005; Suarez-Capello et al., 2006), but generated three progenies (CCN $51 \times$ CSUL 7, CCN $51 \times$ ICS 98 and CCN 51 x OC 67) whose proportion means were among the highest ones (Table 5). Thus, although resistant as a clone, CCN 51 did not have a high general combining ability.

The comparison between progenies which had only one progenitor previously identified as resistant (group 1), whose means are underlined in Table 5 and progenies with two resistant parents (group 2), according to the "per se" evaluation, showed a lower mean for group $2(p<0.01)$. This result indicates that the screening method was efficient in identifying resistance alleles, and that the association of these alleles resulted in an increment of resistance, and, consequently, that the applied breeding methodology achieved its basic purpose.

N'Goran et al. (2006), in the Ivory Coast, also obtained success in enlarging resistance of cacao to Phytophthora palmivora through some specific crosses. Adu-Ampomah et al. (2006), in Ghana, used only one single selection cycle and verified that plants from selected crossings had higher productivity and resistance than the progenitors for resistance to black pod, the principal disease in that country.

Table 3. Proportions of seedlings with disease symptoms, of the progenies from the paternal clones SCA 6, CSUL 7, RB 39, CEPEC 89, OC 67, BE 4, EEG 29 and ICS 98, and the significance of the F test.

\begin{tabular}{lccccccccc}
\hline Clone & Proportion $^{(1)}$ & \multicolumn{9}{c}{ Parentals fathers } \\
\cline { 2 - 9 } & & BE 4 & CEPEC 89 & CSUL 7 & EEG 29 & ICS 98 & OC 67 & RB 39 & SCA 6 \\
\hline BE 4 & 0.49679 & - & 0.2793 & 0.6542 & 0.6398 & 0.0327 & 0.7349 & 0.9632 \\
CEPEC 89 & 0.42475 & - & - & 0.6509 & 0.1191 & 0.0013 & 0.4891 & 0.2645 \\
C.SUL 7 & 0.46175 & - & - & - & 0.4217 & 0.0301 & 0.8847 & 0.6434 & 0.0676 \\
EEG 29 & 0.52566 & - & - & - & - & 0.0817 & 0.4496 & 0.6931 & 0.0007 \\
ICS 98 & 0.63227 & - & - & - & - & - & 0.0206 & 0.0402 & 0.0001 \\
OC 67 & 0.47366 & - & - & - & - & - & - & 0.713 & 0.0171 \\
RB 39 & 0.49989 & - & - & - & - & - & - & - & 0.0041 \\
SCA 6 & 0.29972 & - & - & - & - & - & - & - & - \\
\hline
\end{tabular}

${ }^{(1)} \operatorname{Arc} \sin (\mathrm{x})^{0.5}$. 
Table 4. Proportions of seedlings with disease symptoms, of the progenies from the maternal clones NA 33, CCN 10, IMC 67, P 4B, CCN 51, CEPEC 86, SGU 54 and ICS 9, and the significance of the F test.

\begin{tabular}{lccccccccc}
\hline Clone & Proportion $^{(1)}$ & \multicolumn{9}{c}{ Parentals mothers } \\
\cline { 3 - 9 } & & CCN 10 & CCN 51 & CEPEC 86 & ICS 9 & IMC 76 & NA 33 & P 4B & SGU 54 \\
\hline CCN 10 & 0.3187 & - & 0.0001 & 0.2833 & 0.0001 & 0.0147 & 0.8538 & 0.4185 \\
CCN 51 & 0.6438 & - & - & 0.0001 & 0.7334 & 0.0192 & 0.0001 & 0.0001 & 0.4439 \\
CEPEC 86 & 0.3799 & - & - & - & 0.0004 & 0.1115 & 0.3721 & 0.0599 & 0.0004 \\
ICS 9 & 0.6732 & - & - & - & - & 0.0322 & 0.0001 & 0.0001 & 0.6815 \\
IMC 76 & 0.4814 & - & - & - & - & - & 0.0239 & 0.0018 & 0.0195 \\
NA 33 & 0.3298 & - & - & - & - & - & - & 0.3258 & 0.0001 \\
P 4B & 0.2690 & - & - & - & - & - & - & - & 0.0001 \\
SGU 54 & 0.7189 & - & - & - & - & - & - & - \\
\hline
\end{tabular}

${ }^{(1)} \operatorname{Arc~sin}(\mathrm{x})^{0.5}$.

Table 5. Progenies mean proportions ${ }^{(1)}$ of seedlings with disease symptoms ${ }^{(2)}$.

\begin{tabular}{lccccccccc}
\hline Father Mother & BE 4 & CEPEC 89 & CSUL 7 & EEG 29 & ICS 98 & OC 67 & RB 39 & SCA 6 $^{\text {LSD }}{ }^{(3)}$ \\
\hline CCN 10 & 0.6595 & 0.0959 & - & $\underline{0.2862}$ & $\underline{0.4008}$ & 0.2557 & 0.4019 & 0.1920 & 0.4326 \\
CCN 51 & 0.5687 & 0.6244 & 0.9066 & $\underline{0.4378}$ & $\underline{10.180}$ & 10.049 & 0.4899 & 0.3292 & 0.3956 \\
CEPEC 86 & 0.1007 & 0.3468 & 0.3699 & $\underline{0.6335}$ & $\underline{0.6335}$ & 0.4298 & 0.6335 & 0.1007 & 0.3607 \\
ICS 9 & $\underline{0.6249}$ & - & $\underline{0.8288}$ & - & - & $\underline{0.5677}$ & & - & 0.5062 \\
IMC 76 & 0.6435 & 0.3755 & - & $\underline{0.8663}$ & 0.5807 & 0.4932 & 0.2948 & 0.4070 & 0.5741 \\
NA 33 & 0.2103 & 0.3050 & 0.0000 & $\underline{0.4660}$ & 0.4799 & - & 0.4718 & 0.3823 & 0.4268 \\
P4B & 0.4737 & 0.36243 & - & $\underline{\underline{0.44661}}$ & 0.1338 & 0.16282 & 0.35056 & 0.0000 & 0.319 \\
SGU 54 & $\underline{0.7504}$ & - & - & $\underline{0.7563}$ & - & - & - & - & 0.5113 \\
\hline LSD & 0.5474 & 0.3541 & 0.1812 & 0.5649 & 0.3885 & 0.4288 & 0.3599 & 0.4646 & \\
\hline
\end{tabular}

${ }^{(1)} \operatorname{Arc} \sin (\mathrm{x})^{0.5} \cdot{ }^{(2)}$ Underlined means include only one or not even one father or mother previously identified as resistant, in a previous "per se" field evaluation (Pires, 2003). ${ }^{(3)}$ Least significant difference by Tukey's test, at $5 \%$ of probability, between progeny means and the means of the "per se" evaluation carried out by Pires (2003).

\section{Conclusions}

1. It is possible to obtain a combination of genes to increase the cocoa resistance to witches'-broom directly from the first cycle of recurrent selection.

2. "Per se" evaluations are efficient for selecting cocoa genotypes with potential for high general combining ability.

3. The inoculation using semi-automatic system can be used for early selection since it is a good indicator of the field behaviour of genotypes of cocoa for resistance to witches'-broom.

\section{Acknowledgements}

To Conselho Nacional de Desenvolvimento Científico e Tecnológico, for research grant; to the World Cacao Foundation, whose financial support made this work possible; to Dr. Uilson Vanderlei Lopes and Dr. José Luiz Bezerra, for revisions and valuable suggestions.

\section{References}

ADU-AMPOMAH, Y.; ADOMAKO, B.; OPOKU, I.Y. Cocoa population breeding approaches in Ghana. In: ESKES, A.B.; EFRON, Y. (Ed.). Global approaches to cocoa germplasm utilization and conservation. Amsterdam: Common Fund for Commodities, 2006. p.41-46. (CFC. Technical paper, 50).

BASTOS, C.N.; ALBUQUERQUE, P.S.B. Evaluation of resistance of cocoa genotypes to witches'-broom disease (Crinipellis perniciosa) using phloem sap. Ingenic Newsletter, v.10, p.26-29, 2005.

BAUDOUIN, L.; BARIL, C.; CLÉMENT-DEMANGE, A.; LEROY, T.; PAULIN, D. Recurrent selection of tropical tree crops. Euphytica, v.96, p.101-114, 1997.

CHEESMAN, E.E. Notes on the nomenclature, classification and possible relationships of cacao populations. Tropical Agriculture, v.21, p.144-159, 1944.

COCHARD, B.; NOIRET, J.M.; BAUDOUIN, L.; AMBLARD, P. Second cycle de sélection récurrente réciproque chez le palmier à huile Elaeis guineensis jacq: résultats des tests d'hybrides Deli x La Mé. Oléagineux, v.48, p.441-451, 1993. 
COMSTOCK, R.E.; ROBINSON, H.F. Estimation of overage dominance of genes. In: GOWEN, J.W. (Ed.). Heterosis. Iowa State: Iowa State College, 1952. p.494-516.

FRIAS, G.A. Inoculation method to evaluate resistance to witches'-broom disease of cacao. 1987. 111p. Thesis (PhD) University of Florida, Gainesville.

FRIAS, G.A.; PURDY, L.H.; SCHMIDT, L.H. An inoculation method for evaluating resistance of cacao to Crinipellis perniciosa. Plant Disease, v.79, p.787-791, 1995.

LEROY, T.; MONTAGNON, C.; CILAS, C.; YAPO, A.; CHARMETANT, P.; ESKES, A.B. Reciprocal recurrent selection applied to Coffea canephora Pierre. III. Genetic gains and results of first cycle intergroup crosses. Euphytica, v. 95, p.347-354, 1997.

LOCKWOOD, G.; PANG, J.T.Y. Additive inheritance of yield in cocoa. In: INTERNATIONAL COCOA RESEARCH CONFERENCE, 11., 1993, Yamoussoukro. Proceedings. Yamoussoukro: Cocoa Producers' Alliance, 1993. p.415-423.

LUZ, E.D.M.N.; BEZERRA, J.L.; RESENDE, M.L.V. de; OLIVEIRA, M.L. de. Cacau (Theobroma cacao L.) controle de doenças. In: VALE, F.X.R. do; ZAMBOLIM, L. (Ed.). Controle de doenças de plantas. Viçosa: UFV, 1997. p.611-655.

MONTEIRO, W.R.; LOPES, U.V.; PIRES, J.L.; YAMADA, M.M.; MARQUES, J.R.B.; LUZ, E.D.M.N.; MIDLEJ, S.D.V.; PAIM, M.C.A. Population breeding activities in Brazil. In: ESKES, A.B.; EFRON, Y. (Ed.). Global approaches to cocoa germplasm utilization and conservation. Amsterdam: Common Fund for Commodities, 2006. p.28-24. (CFC. Technical paper, 50).

N'GORAN, J.A.K.; LACHENAUD, P.; KÉBÉ, I.B.; N'GUESSAN, F.; TAHI, M.; POKOU, D.; SOUNIGO, O.; N'GORAN, K.; ESKES, A.B. Population breeding approaches applied in cocoa selection in Côte d'Ivoire. In: ESKES, A.B.; EFRON, Y. (Ed.). Global approaches to cocoa germplasm utilization and conservation. Amsterdam: Common Fund for Commodities, 2006. p.35-40. (CFC. Technical paper, 50).

PAULIN, D.Les méthodes de sélection du cacaoyer. In: SÉMINAIRE DE BIOMÉTRIE ET GÉNÉTIQUE QUANTITATIVE, 1994, Montpellier. Traitements statistiques des essais de sélection: stratégies d'amélioration des plantes pérennes: actes. Montpellier: CIRAD-CP, 1995. p.243-257.

PEREIRA, J.L.; RAM, A.; FIGUEIREDO, J.M.; ALMEIDA, L.C. Primeira ocorrência da vassoura-de-bruxa na principal região produtora de cacau do Brasil. Agrotrópica, v.1, p.70-81, 1989.

PIRES, J.L. Avaliação quantitativa e molecular de germoplasma para o melhoramento do cacaueiro com ênfase na produtividade, qualidade de frutos e resistência a doenças. 2003. 328p. Tese (Doutorado) - Universidade Federal de Viçosa, Viçosa.
PIRES, J.L.; MONTEIRO, W.R.; PINTO, L.R.M.; FIGUEIRA, A.; YAMADA, M.M.; AHNERT, D.A. Proposal for cacao breeding. In: INTERNATIONAL COCOA RESEARCH CONFERENCE, 12., 1999, Salvador. Proceedings. Salvador: Cocoa Producers' Alliance, 1999. p.287-292.

POKOU, D.; N'GORAN, J.K.A.; LACHENAUD, P.; ESKES A.; MONTAMAYOR, J.C.; SCHNELL, R.J.; KOLESNIKOVA-ALLEN, M.; CLÉMENT, D.; SANGARÉ A. Recurrent selection of cocoa populations in Côte d'Ivoire: comparative genetic diversity between the first and second cycles. Plant Breeding, v.128, p.514-520, 2009.

ROCHA, H.M.; WHEELER, B.E.J. Factors influencing the production of basidiocarps and the deposition and germination of basidiospores of Crinipellis perniciosa, the causal fungus of witches'-broom on cocoa (Theobroma cacao). Plant Pathology, v.34, p.319-328, 1985.

SAS INSTITUTE. SAS/STAT: user's guide. Release 6.03. Cary: SAS Institute, 1988. 1028p.

SILVA, S.D.V.M.; LUZ, E.D.M.N.; BEZERRA, J.L. Standardization of the belt system method to assess cacao genotypes to witches'-broom resistance. In: INTERNATIONAL COCOA RESEARCH CONFERENCE, 13., 2000, Kota Kinabalu. Proceedings. Kota Kinabalu: Cocoa Producers' Alliance, 2000. p.503-510.

SUAREZ-CAPELLO, C. Growth of Crinipellis perniciosa (Stahel) Singer in vivo and in vitro. 1977. 134p. Thesis (PhD) University of London, London.

SUAREZ-CAPELLO, C.; DELGADO, R.; POZO, P. del; VASCO, A.; ZAMBRANO, J.; ESKES, A.B.; AMORES, F.M. Witches'-broom resistance screening of seedlings and clones in Ecuador: some comparisons between natural infection in the field and artificial inoculations. In: ESKES, A.B.; EFRON, Y. (Ed.). Global approaches to cocoa germplasm utilization and conservation. Amsterdam: Common Fund for Commodities, 2006. p.151-157. (CFC. Technical paper, 50).

SURUJDEO-MAHARAJ, S.; UMAHARAN, P.; BUTLER, D.R. Assessment of resistance to witches'-broom disease in clonal and segregating populations of Theobroma cacao. Plant Disease, v.88, p.797-803, 2004.

TREVISAN, S.D.P. Mudanças no sul da Bahia associadas à vassoura-de-bruxa do cacau. In: INTERNATIONAL COCOA RESEARCH CONFERENCE, 12., 1999, Salvador. Proceedings. Salvador: Cocoa Producers' Alliance, 1999. p.1109-1116.

WADSWORTH, R.M.; FORD, C.S.; END, M.J.; HADLEY, P. International cocoa germplasm database. London: LIFFE, 1997. 878p.

$\overline{\text { Received on July 29, } 2009 \text { and accepted on June 15, } 2010}$ 